\title{
BURNOUT PADA KELUARGA PASIEN DI RUANG PEDIATRIC INTENSIVE CARE UNIT (PICU) RSUD ULIN BANJARMASIN
}

\author{
Safriana Nur Awaliah Akbar \\ Politeknik Kesejahteraan Sosial Bandung. Rianaawaliah4@gmail.com \\ Aep Rusmana \\ Politeknik Kesejahteraan Sosial Bandung, aeprusmana6@gmail.com \\ Moch Zaenal Hakim \\ Politeknik Kesejahteraan Sosial Bandung, jejenhkm@yahoo.com
}

\begin{abstract}
The purpose of this study is to describe the empirical condition of burnout on the patient's family in Pediatric Intensive Care Unit (PICU) at RSUD ULIN Banjarmasin. This research uses a quantitative approach with descriptive methods. The objects in this research were aggerated to the maximum total of 30 respondents obtained through saturated sampling techniques. In this study, the research measurement tool used Likert scale, in which used to measure attitudes, opinions and perceptions of a person or group. Meanwhile, the data collection techniques that used in this study were questionnaires and study documentation. The results of this study were analyzed with one variable using descriptive statistical techniques through tables and continuum lines by paying attention to the percentage of total score.

The results of this study indicate that burnout of the patient's family in the Pediatric Intensive Care Unit at RSUD ULIN Banjarmasin is in the high category, it is shown in three dimensions which are emotional exhaustion, physical exhaustion and mental exhaustion. Therefore to reduce burnout on the patient's family, the researcher proposed a program named "Efforts to Reduce the Burnout Rate of Critical Patients' Family Through Self Help Groups". The method that were used in this program is group work method with confrontation, interpretation and support techniques. The activities that will be included in this program are group discussions and role playing.
\end{abstract}

Keywords: Burnout; Patient's Family; Intensive Care Unit.

\begin{abstract}
Abstrak
Tujuan penelitian ini adalah untuk mengetahui gambaran empiris mengenai kondisi burnout pada keluarga pasien di Ruang Pediatric Intensive Care Unit (PICU) di RSUD ULIN Banjarmasin. Penelitian ini menggunakan pendekatan kuantitiatif dengan metode deskriptif. Adapun objek dalam penelitian ini adalah sebanyak 30 responden yang diperoleh melalui teknik pengambilan sampel jenuh. Sedangkan teknik pengumpulan data yang digunakan dalam penelitian ini adalah melalui kuesioner dan studi dokumentasi. Dalam penelitian ini, alat ukur penelitian menggunakan skala likert, yang mana skala likert digunakan untuk mengukur sikap, pendapat, dan persepsi seseorang atau kelompok. Adapun
\end{abstract}


hasil penelitian ini dianalisis dengan satu variabel menggunakan teknik statistik deskriptif melalui tabel-tabel dan garis kontinum dengan memperhatikan persentase skor total.

Hasil penelitian ini menunujukkan bahwa burnout pada keluarga pasien di Ruang Pediatric Intensive Care Unit (PICU) di RSUD ULIN Banjarmasin berada pada kategori tinggi, hal tersebut ditunjukkan pada tiga dimensi yakni kelelahan emosional, kelelahan fisik dan kelelahan mental. Maka dari itu untuk mengurangi burnout pada keluarga pasien, peneliti mengusulkan program "Upaya Pengurangan Tingkat Burnout Keluarga Pasien Melalui Kelompok Bantu Diri (Self Help Group)". Metode yang digunakan adalah metode group work dengan teknik konfrontasi, intrepertasi dan support dengan kegiatan diskusi kelompok dan role playing

Kata Kunci: Burnout; Keluarga Pasien; Ruang Perawatan Intensif

\section{PENDAHULUAN}

Ruang Pediatric Intensive Care Unit (PICU) adalah ruang perawatan intensif di rumah sakit bagi anak dengan gangguan kesehatan serius atau yang berada dalam kondisi kritis. Ruang PICU adalah bagian dari Ruang Intensive Care Unit (ICU) atau unit pelayanan intensif di rumah sakit. Atika dan Halimuddin (2018) menyatakan bahwa ruang Intensive Care merupakan ruangan yang penuh stres (stressful place) tidak hanya bagi pasien yang dirawat tetapi juga bagi keluarga. Penyakit kritis yang dialami salah satu anggota keluarga berdampak negatif pada seluruh keluarga. Masuknya anggota keluarga sebagai pasien di unit pelayanan intensif dapat memicu krisis keluarga. Minuchin dalam Nadirawati (2018) menyebutkan bahwa krisis keluarga yang dihadapi ketika salah satu anggota keluarga dirawat di rumah sakit merupakan sumber stressor situasional. Dalam hal ini, keluarga pasien penyakit kritis yang diserang oleh stressor situasional secara terus menerus, akan dihadapkan dengan kondisi ketegangan.

Jacob dalam Atika dan Halimuddin (2018) menyatakan bahwa penyakit kritis yang diderita orang yang dicintai memiliki efek yang sangat besar pada anggota keluarga pasien, hal ini terjadi karena ada keyakinan bahwa tidak ada penderitaan yang lebih berat selain kehilangan keluarga. Pendapat tersebut sejalan dengan pendapat yang dikemukakan oleh Friedman (2003) bahwa, satu diantara lima kejadian yang dapat menimbulkan stres pada keluarga adalah kematian anggota keluarga. Selain mengalami stres dan ketengangan, anggota keluarga pasien yang menderita sakit kritis mengalami gejala psikologis lainnya seperti stres pasca-trauma (PTSD), kecemasan, dan depresi selama orang yang mereka cintai mengalami penyakit kritis.

Berdasarkan penelitian yang dilakukan oleh Jacka, Mitchell, \& Perezparada (2016) di salah satu rumah sakit Amerika Serikat terdapat $33 \%$ dari keluarga pasien di ruang perawatan kritis mengalami PTSD, 33\% mengalami kecemasan dan $20 \%$ mengalami depresi. Penelitian lain dilakukan di Chile dengan hasil penelitian yakni mencapai $23 \%$ keluarga pasien mengalami gangguan psikologis. (Silva et al., 2017). Kemudian, penelitian yang dilakukan oleh Paparrigopoulo di Yunani mengukur kualitas hidup secara jangka pendek, pada anggota keluarga pasien 
ICU dalam poin waktu yang berbeda-beda. Pada 1 minggu setelah pasien masuk, 97\% anggota keluarga mengalami depresi dan $81 \%$ anggota keluarga mengalami stres. Sedangkan 3 hari sebelum pasien dipindahkan dari ruangan ICU dengan kondisi pasien yang sudah membaik, dinyatakan sebanyak $87 \%$ anggota keluarga masih mengalami depresi dan 59\% anggota keluarga masih mengalami stres pasca trauma (PTSD).

Hasil penelitian yang telah dilakukan di negara Amerika Serikat, Chile, dan Yunani menunjukkan bahwa keadaan penyakit kritis pada pasien menghadapkan keluarga pada tekanan psikologis. Tekanan psikologis yang dihadapi keluarga merupakan stimulus atau stressor yang mendorong sistem dalam keluarga untuk melakukan banyak perubahan. Hill dalam Friedman (2003) menyatakan bahwa perubahan yang dialami keluarga ketika mengalami stres dapat meliputi perubahan interaksi sosial dan budaya, perubahan ekonomi hingga perubahan kondisi kesehatan, dalam hal ini mencakup baik kesehatan fisik ataupun mental. Perubahan-perubahan tersebut dialami oleh keluarga sebagai bentuk respon dari stres. Menurut penelitian yang dilakukan oleh Zahara, Kusman, dan Aat (2014) disebutkan bahwa kondisi stres yang dialami oleh keluarga pasien di ruang perawatan intensif dapat memicu stres berat pada keluarga yang dapat berlanjut pada kondisi kelelahan, gangguan fisik, gangguan psikologis serta ketidakberdayaan keluarga. Keluarga akan dipenuhi dengan perasaan persalah, disorientasi, kelelahan, keputusasaan, kemarahan, penolakan dan juga ketakutan akan kehilangan anggota keluarga yang dicintainya yang dapat menyebabkan kondisi ketidakseimbangan dalam keluarga.
(Verhaeghe ST, Van Zuuren FJ, Defloor T, Duijnstee MS \& Grypdonck MH, 2007).

Gejala-gejala psikologis yang telah disebutkan merupakan sindrom dari fenomena burnout yang sebagaimana dijelaskan oleh Maslach (2014) bahwa burnout merupakan sindrom kelelahan emosional, depersonalisasi dan penurunan rasa berkebolehan diri yang dialami individu-individu yang bekerja dan berurusan dengan orang lain. Burnout merupakan respon kepada tekanan emosional yang kronik akibat berurusan secara intensif dengan manusia lain khususnya mereka yang menghadapi masalah. Pendapat ini sejalan dengan pendapat Sujipto (2001) yang mendefinisikan burnout suatu bentuk ketegangan atau tekanan psikis yang berhubungan dengan stres kronik, dialami seseorang dari hari ke hari yang ditandai dengan kelelahan fisik, mental dan emosional.

Dalam hal ini keluarga pasien khususnya orang tua pasien sangat rentan mengalami kondisi burnout. Hal ini disebabkan oleh faktor tekanan psikologis yang dihadapi oleh orang tua ketika anaknya sedang mengalami perawatan intensif. Tekanan psikologis dan stres yang dirasakan dalam kurun waktu yang lama akan menyebabkan kelelahan baik kelelahan secara fisik, emosional dan mental.

Untuk membuktikan kondisi burnout pada keluarga pasien secara nyata di lapangan, sebelum melakukan penelitian lebih lanjut, peneliti melakukan wawancara langsung kepada 4 orang anggota keluarga pasien kritis di ruang PICU RSUD ULIN Banjarmasin dengan tujuan untuk mengetahui gejala-gejala atau sindrom apa saja yang dirasakan oleh keluarga pasien. Hasilnya 4 orang keluarga pasien mengalami kecemasan dan ketakutan dengan keluarganya yang kritis, 3 orang 
mengalami gangguan tidur karena tidak terbiasa dengan kondisi rumah sakit, tidak terbiasa tidur di lantai beralaskan tikar, merasa tidak tenang pikirannya dan sering terbangun karena adanya panggilan dari ruang PICU di malam hari. Diketahui bahwa 3 orang mengalami tidak enak badan dan merasakan sakit dan 4 orang mengalami gangguan dalam berhubungan sosial karena tidak mampu beraktivitas seperti biasa, tidak bisa melakukan pekerjaan seperti biasa dan tidak dapat bersosialisasi. Diketahui dari hasil wawancara sebanyak 4 orang keluarga pasien memiliki permasalahan keuangan karena tidak dapat bekerja sedangkan keluarga memerlukan biaya untuk perawatan pasien.

Berdasarkan hasil wawancara tersebut, maka diketahui bahwa keluarga pasien memiliki gejala-gejala burnout yang dikategorikan ke dalam dimensi kelelahan emosional yang ditunjukkan dengan perasaan cemas dan perasaaan ketakutan yang disebabkan oleh kondisi kesehatan pasien di dalam Ruang PICU. Adapun ditinjau dari dimensi kelelahan fisik, keluarga pasien juga diketahui mengalami kesulitan untuk tidur di malam hari, merasa gelisah dan tidak merasa tenang sehingga menyebabkan terganggunya kualitas istirahat keluarga pasien pada malam hari. Sedangkan ditinjau dari dimensi kelelahan mental, tidak banyak yang dapat tergambarkan dari hasil wawancara singkat yang dilakukan peneliti, namun ditinjau dari kondisi kelelahan emosional dan fisik yang dirasakan oleh keluarga pasien dan dari jawaban keluarga pasien atas pertanyaan terkait dengan konsep diri dan hubungan sosial, dapat disimpulkan bahwa keluarga pasien cenderung mudah memiliki persepsi yang negatif baik untuk orang lain ataupun dirinya sendiri dan hal ini berdampak pada kurangnya kepekaan sosial keluarga pasien terhadap orang lain dan kesulitan keluarga untuk bersosialisasi dengan orang orang di lingkungan sekitar.

Berdasarkan fenomena yang telah dijabarkan diatas maka peneliti tertarik untuk meneliti isu kondisi burnout pada keluarga pasien di ruang Pediatric Intensive Care Unit (PICU) RSUD ULIN Banjarmasin. Harapan peneliti, penelitian ini dapat berguna bagi keluarga pasien untuk menambah pengetahuan yang berkaitan dengan kondisi kesehatannya baik secara emosional, mental dan fisiknya. Hal ini dikarenakan kesehatan anggota keluarga dan kualitas kesehatan mempunyai hubungan yang erat dan status sehat ataupun sakit para anggota keluarga saling mempengaruhi satu sama lain (Nadirawati, 2018). Diharapkan keluarga pasien dapat mengetahui seberapa pentingnya menjaga kesehatan dirinya dan memiliki family coping strategy yang tepat dan sesuai karena kondisi stres yang dialami oleh keluarga dapat menghambat kemampuan keluarga dalam memberikan dukungan anggota keluarganya yang sedang dirawat di ruang perawatan intensif. Kemajuan dan kesembuhan perawatan pasien kritis juga dipengaruhi oleh dukungan dan keberadaan keluarga dekat pasien yang sedang berjuang menjalani proses perawatan intensif. Selain diharapkan berguna bagi keluarga pasien, penelitian ini juga diharapkan dapat berguna bagi pihak rumah sakit, terutama bagi pihak medis dan pihak instalasi psikologi RSUD ULIN Banjarmasin. Diharapkan melalui penelitian ini, pihak rumah sakit dapat lebih mempertimbangkan kondisi keluarga pasien kritis ke dalam pelayanan rumah sakit dengan bentuk asuhan keperawatan serta rumah sakit diharapkan dapat memperbaiki dan menambah fasilitas infrastruktur 
khususnya bagi para penunggu pasien kritis di ruang perawatan intensif.

\section{METODE}

Metode yang digunakan dalam penelitian ini adalah metode deskriptif dengan pendekatan kuantitatif. Sumber data dalam penelitian ini meliputi sumber data primer dan sumber data sekunder. Sumber data primer diperoleh dari jawaban kuesioner responden dan hasil wawancara singkat Responden yang dimaksud dalam penelitian ini adalah keluarga pasien yang terdaftar sebagai pendamping pasien anak selama proses perawatan intensif di ruang PICU. Adapun data sekunder dalam penelitian ini merupakan sumber data yang didapatkan dari data laporan, file arsip yang berhubungan dengan permasalahan penelitian yang diperoleh dari pihak rumah sakit, instalasi pelayanan intensif, perawat, dokter serta apoteker yang bekerja di ruang Pediatric Intensive Care Unit (PICU) RSUD ULIN Banjarmasin.

Sasaran populasi dalam penelitian ini adalah seluruh keluarga pasien yang dirawat di Ruang PICU. Adapun teknik penarikan sampel yang digunakan peneliti adalah jenis nonprobability sampling dengan teknik sampling jenuh. Fenti Hikmawati (2019) mengatakan bahwa teknik sampling jenuh merupakan teknik penentuan sampel dengan mengambil seluruh anggota populasi sebagai sampel jika jumlah populasi relatif kecil, maksimal 30 orang, atau penelitian yang ingin membuat generalisasi dengan kesalahan yang sangat kecil. Dalam penelitian ini responden berjumlah 30 orang.

Pengukuran variabel burnout dalam penelitian ini adalah menggunakan alat ukur yaitu instrumen penelitian yang berupa kuesioner yang disusun dalam bentuk skala likert. Skala likert digunakan untuk mengukur sikap, pendapat, dan persepsi seseorang atau suatu kelompok orang tentang fenomena sosial. (Sugiyono, 2016).

Uji validitas yang digunakan dalam penelitian ini adalah validitas muka (face validity). Penelitian ini menggunakan pengujian realibilitas instrumen dengan menggunakan teknik Alpa Cornbach dengan hasil sebesar 0,989. Adapun pengumpulan data dalam penelitian ini diperoleh melalui teknik penyebaran kuesioner, wawancara dan studi dokumentasi.

\section{HASIL PENELITIAN}

\section{Karakteristik Responden}

Karakteristik responden dalam penelitian ini diklasifikasikan ke dalam beberapa kriteria yaitu berdasarkan jenis kelamin, berdasarkan usia, dan berdasarkan status anggota keluarga pasien di Ruang PICU. Diketahui berdasarkan hasil penelitian sebanyak $63 \%$ responden berjenis kelamin perempuan dan sebanyak $37 \%$ responden berjenis kelamin laki-laki. Karakteristik responden berdasarkan jenis kelamin didominasi oleh responden dengan jenis kelamin perempuan. Hal ini disebabkan karena mayoritas responden adalah ibu kandung dari pasien yang menunggu dan menemani pasien dalam menjalani proses perawatan intensif di Ruang PICU.

Selanjutnya karakteristik reponden ditinjau berdasarkan usia, diketahui responden dalam penelitian ini sebagian besar berusia antara 20 - 30 tahun yakni sebanyak 18 orang. Mayoritas keluarga atau yang menjadi pendamping dan penunggu pasien di Ruang PICU tergolong dalm usia muda dan produktif. Adapun karakteristik responden berdasarkan status anggota keluarga pasien di 
Ruang PICU adalah sebanyak $90 \%$ atau sebanyak 27 orang responden berstatus sebagai orang tua pasien. Sebanyak $7 \%$ atau 2 orang keluarga pasien berstatus sebagai saudara kandung keluarga pasien dan sebanyak 3\% atau 1 orang keluarga pasien berstatus nenek dari pasien. Diketahui mayoritas penunggu dan pendamping pasien selama menjalani proses perawatan di Ruang PICU RSUD ULIN Banjarmasin adalah keluarga yang berstatus sebagai orang tua pasien.

\section{Dimensi Kelelahan Emosional Keluarga Pasien di Ruang PICU}

Kelelahan emosional meliputi kelelahan yang terkait dengan perasaan pribadi dengan ciri-ciri atau gejala seperti bosan, putus asa, mudah tersinggung, depresi, merasa tertekan, tidak berdaya, sedih yang mendalam, gelisah, dan mudah marah.

Tabel 1 : Rekapitulasi Dimensi Kelelahan

\begin{tabular}{|c|c|c|c|}
\hline \multicolumn{4}{|c|}{ Emosional (Emotional Exhaustion) } \\
\hline No & Pernyataan & $\begin{array}{c}\text { Skor } \\
\text { Aktual }\end{array}$ & $\begin{array}{l}\text { Skor } \\
\text { Ideal }\end{array}$ \\
\hline 1 & $\begin{array}{l}\text { Merasa bosan karena } \\
\text { aktivitas di rumah sakit } \\
\text { yang monoton. }\end{array}$ & 99 & 150 \\
\hline 2 & $\begin{array}{l}\text { Tingginya tarif } \\
\text { perawatan rumah } \\
\text { sangat membebani }\end{array}$ & 103 & 150 \\
\hline 3 & $\begin{array}{l}\text { Merasa putus asa dengan } \\
\text { kondisi kritis anak yang } \\
\text { sedang di rawat di ruang } \\
\text { PICU }\end{array}$ & 89 & 150 \\
\hline 4 & $\begin{array}{lll}\begin{array}{l}\text { Perasaan } \\
\text { mendalam }\end{array} & \text { sedih } & \text { yang } \\
\end{array}$ & 130 & 150 \\
\hline 5 & $\begin{array}{l}\text { Menjadi sensitif dan } \\
\text { mudah marah }\end{array}$ & 114 & 150 \\
\hline 6 & $\begin{array}{l}\text { Gelisah setiap melihat } \\
\text { perkembangan kesehatan } \\
\text { anak di ruang PICU }\end{array}$ & 124 & 150 \\
\hline 7 & $\begin{array}{l}\text { Sering merasa tersinggung } \\
\text { dengan orang dan } \\
\text { pelayanan di lingkungan } \\
\text { rumah sakit. }\end{array}$ & 74 & 150 \\
\hline
\end{tabular}

Skor Maksimal atau Ideal $=$ Nilai Tertinggi $\mathrm{x}$ Jumlah Soal x Jumlah Responden.

$$
\begin{aligned}
& =5 \times 7 \times 30 \\
& =1050
\end{aligned}
$$

Skor Minimal $=$ Nilai Terendah $\mathrm{x}$ Jumlah Soal $\mathrm{x}$ Jumlah Responden.

$$
\begin{aligned}
& =1 \times 7 \times 30 \\
& =210
\end{aligned}
$$

Range $=$ Total Skor Maksimum - Total Skor Minimum.

$$
\begin{aligned}
& =1050-210 \\
& =840
\end{aligned}
$$

Kategori / Kelas $(K) \quad=3$

Interval $(i)$ dengan rumus $=$

$$
i=\frac{\mathrm{R}}{K}=\frac{840}{3}=280
$$

Berdasarkan perhitungan tersebut, maka batas skor untuk setiap kategori sebagai berikut :

$210-420=$ Rendah

$421-630=$ Sedang

$631-840-$ Tinggi

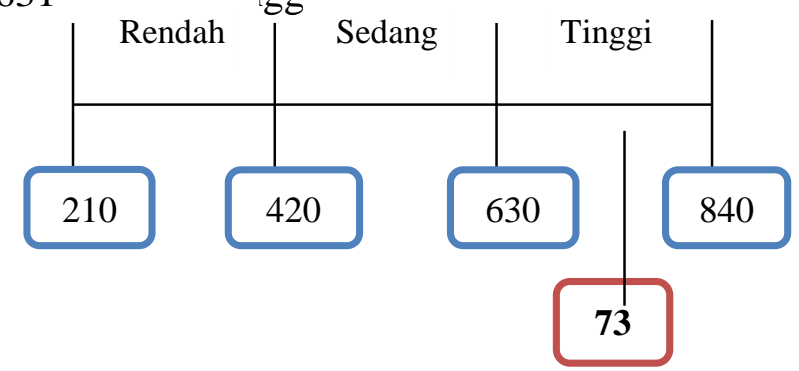

Total skor aktual adalah hasil perhitungan skor pada kategori skala sangat setuju, setuju, kurang setuju, tidak setuju dan sangat tidak setuju. Berdasarkan hasil rekapitulasi, dimensi kelelahan emosional menghasilkan skor sebesar 733 dan termasuk dalam kategori tinggi. Hal tersebut menunjukkan bahwa sebagian besar responden yakni keluarga pasien mengalami kelelahan emosional pada saat menunggu dan mendampingi pasien selama proses perawatan intensif di Ruang PICU.

\section{Dimensi Kelelahan Fisik Keluarga Pasien di Ruang PICU}

Kelelahan fisik (physical exhaustion) adalah kelelahan yang berkaitan dengan keadaan fisik yang dicirikan seperti kesulitan bangun di pagi hari, sering terkena flu, 
perubahan kebiasaan makan, kesulitan tidur di malam hari, sakit kepala, tegang pada otot leher dan bahu, dan rasa sakit di punggung. Sementara energi fisik dicirikan sebagai energi yang rendah, rasa letih yang kronis dan lemas. Tabel 2 : Rekapitulasi Dimensi Kelelahan Fisik (Physical Exhaustion)

\begin{tabular}{clcc}
\hline No & \multicolumn{1}{c}{ Pernyataan } & $\begin{array}{c}\text { Skor } \\
\text { Aktual }\end{array}$ & $\begin{array}{c}\text { Skor } \\
\text { Ideal }\end{array}$ \\
\hline 1 & $\begin{array}{l}\text { Merasa lelah dan kesulitan } \\
\text { bangun pagi setiap harinya }\end{array}$ & 125 & 150 \\
\hline 2 & $\begin{array}{l}\text { Terlalu lama berada dalam } \\
\text { ruangan PICU yang ber-ac } \\
\text { menyebabkan saya sering } \\
\text { terkena flu }\end{array}$ & 108 & 150 \\
\hline 3 & $\begin{array}{l}\text { Merasa tidak nafsu makan } \\
\text { sejak anak dirawat di ruang } \\
\text { PICU }\end{array}$ & 116 & 150 \\
\hline 4 & $\begin{array}{l}\text { Kesulitan tidur di malam } \\
\text { hari }\end{array}$ & 110 & 150 \\
\hline 5 & $\begin{array}{l}\text { Menjadi sering merasa } \\
\text { sakit kepala/migrain }\end{array}$ & 117 & 150 \\
\hline 6 & $\begin{array}{l}\text { Aktivitas menunggu anak } \\
\text { di ruangan PICU } \\
\text { menyebabkan leher dan } \\
\text { bahu terasa sakit }\end{array}$ & 118 & 150 \\
\hline 7 & $\begin{array}{l}\text { Berada dalam posisi duduk } \\
\text { dalam jangka waktu yang } \\
\text { lama membuat punggung } \\
\text { saya terasa sakit }\end{array}$ & & \\
\hline \multicolumn{1}{c}{ Jumlah } & $\mathbf{8 1 3}$ & 1.050 \\
\hline
\end{tabular}

Skor Maksimal atau Ideal $=$ Nilai Tertinggi $\mathrm{x}$ Jumlah Soal x Jumlah Responden.

$$
\begin{aligned}
& =5 \times 7 \times 30 \\
& =1050
\end{aligned}
$$

Skor Minimal $=$ Nilai Terendah $\mathrm{x}$ Jumlah Soal $\mathrm{x}$ Jumlah Responden.

$$
\begin{aligned}
& =1 \times 7 \times 30 \\
& =210
\end{aligned}
$$

Range $=$ Total Skor Maksimum - Total Skor Minimum.

$\begin{aligned} & =1050-210 \\ & =84 \\ \text { Kategori } / \text { Kelas }(K) & =3 \\ \text { Interval }(i) \text { dengan rumus } & =\end{aligned}$

$$
i=\frac{\mathrm{R}}{K}=\frac{840}{3}=280
$$

Berdasarkan perhitungan tersebut, maka batas skor untuk setiap kategori sebagai berikut : $210-420=$ Rendah
$421-630=$ Sedang

$631-840=$ Tinggi

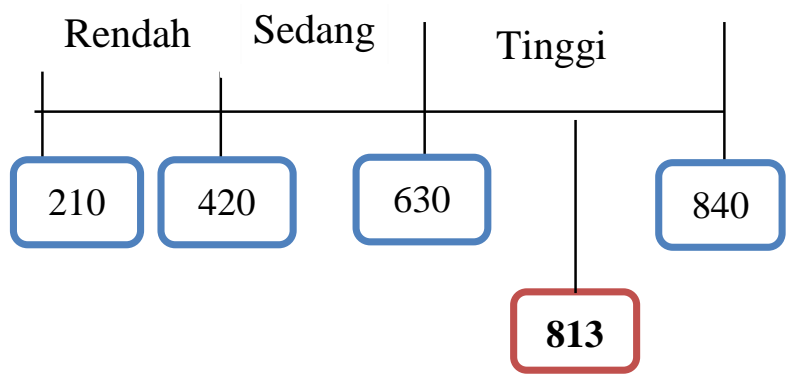

Total skor aktual adalah hasil perhitungan skor pada kategori skala sangat setuju, setuju, kurang setuju, tidak setuju dan sangat tidak setuju. Hasil rekapitulasi nilai dimensi kelelahan fisik menghasilkan skor sebesar 813 yang termasuk dalam kategori tinggi. Hal tersebut menunjukkan bahwa responden yakni keluarga pasien mengalami kelelahan fisik saat menunggu dan mendampingi pasien di ruang PICU.

\section{Dimensi Kelelahan Mental Keluarga Pasien di Ruang PICU \\ Kelelahan mental (mental exhaustion)} merupakan rendahnya penghargaan diri dan depersonalisasi yang ditandai dengan merasa kurang peduli dengan dirinya, pekerjaannya dan kehidupannya, merasa gagal, tidak berdaya dan tidak kompeten, kurang bersimpati pada orang lain serta tidak puas dengan jalan hidupnya sendiri.

Tabel 3 : Rekapitulasi Dimensi Kelelahan Mental (Mental Exhaustion)

\begin{tabular}{clcc}
\hline No & \multicolumn{1}{c}{ Pernyataan } & $\begin{array}{c}\text { Skor } \\
\text { Aktual }\end{array}$ & $\begin{array}{c}\text { Skor } \\
\text { Ideal }\end{array}$ \\
\hline 1 & $\begin{array}{l}\text { Kurang memperhatikan } \\
\text { kesehatan diri sendiri dan } \\
\text { hanya memperdulikan } \\
\text { kesehatan anak, sejak anak } \\
\text { dirawat di ruang PICU }\end{array}$ & 89 & 150 \\
\hline 2 & $\begin{array}{l}\text { Merasa kesulitan } \\
\text { menciptakan suasana yang } \\
\text { rileks dengan anak }\end{array}$ & 99 & 150 \\
\hline 3 & $\begin{array}{l}\text { Tidak mempunyai banyak } \\
\text { waktu dan merasa kurang } \\
\text { empati dan peduli dengan } \\
\text { orang lain }\end{array}$ & & \\
\hline
\end{tabular}




\begin{tabular}{|c|c|c|c|}
\hline 4 & $\begin{array}{l}\text { Merasa gagal melakukan } \\
\text { tugas sebagai orang tua } \\
\text { dalam hal pengasuhan dan } \\
\text { perawatan }\end{array}$ & 82 & 150 \\
\hline 5 & $\begin{array}{l}\text { Merasa kurangnya } \\
\text { perhatian dan kepedulian } \\
\text { perawat dan dokter yang } \\
\text { menangani anak saya di } \\
\text { ruang PICU }\end{array}$ & 79 & 150 \\
\hline 6 & $\begin{array}{l}\text { Merasa diri saya sendiri } \\
\text { yang menjadi penyebab } \\
\text { anak / keluarga saya sakit }\end{array}$ & 79 & 150 \\
\hline & Jumlah & 524 & 900 \\
\hline
\end{tabular}

Skor Maksimal atau Ideal $=$ Nilai Tertinggi $\mathrm{x}$ Jumlah Soal x Jumlah Responden.

$$
\begin{aligned}
& =5 \times 7 \times 30 \\
& =1050
\end{aligned}
$$

Skor Minimal $=$ Nilai Terendah $\mathrm{x}$ Jumlah Soal $\mathrm{x}$ Jumlah Responden.

$$
\begin{aligned}
& =1 \times 6 \times 30 \\
& =180
\end{aligned}
$$

Range $=$ Total Skor Maksimum - Total Skor Minimum.

$$
\begin{aligned}
& =900-180 \\
& =720
\end{aligned}
$$

Kategori / Kelas $(K) \quad=3$

Interval $(i)$ dengan rumus $=$

$$
i=\frac{\mathrm{R}}{K}=\frac{720}{3}=240
$$

Berdasarkan perhitungan tersebut, maka batas skor untuk setiap kategori sebagai berikut :

$$
\begin{aligned}
& 180-360=\text { Rendah } \\
& 361-540=\text { Sedang } \\
& 541-720=\text { Tinggi }
\end{aligned}
$$

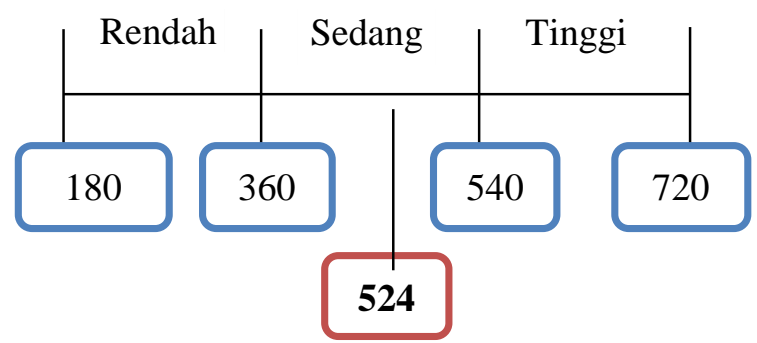

Total skor aktual adalah hasil perhitungan skor pada kategori skala sangat setuju, setuju, kurang setuju, tidak setuju dan sangat tidak setuju. Hasil rekapitulasi nilai dimensi kelelahan mental menghasilkan skor 524 dan termasuk dalam kategori sedang. Kelelahan mental yang dirasakan responden pada saat menunggu dan mendampingi pasien di Ruang PICU tidak lepas dari pengaruh kelelahan emosional dan kelelahan fisik yang dirasakan oleh responden.

\section{PEMBAHASAN}

\section{Analisis Hasil Penelitian}

\section{a. Dimensi Kelelahan Emosional}

Berdasarkan penelitian yang telah dilakukan, diketahui bahwa pasien yang menjalani seluruh perawatan intensif di ruang PICU menyebabkan keluarga pasien berada dalam kondisi kelelahan secara emosional. kelelahan emosional yang dirasakan keluarga pasien dimunculkan melalui perasaan sedih yang mendalam ketika keluarga pasien melihat pasien menjalani perawatan intensif di Ruang PICU, kecemasan yang dirasakan keluarga pasien setiap kali melihat perkembangan kesehatan pasien. informasi yang diperoleh peneliti melalui perawat yang bekerja di ruang PICU bahwa para keluarga pasien sering mengalami pingsan di ruang PICU ketika kondisi kesehatan pasien mengalami penurunan drastis. Keluarga pasien juga menjadi merasa lebih sensitif terhadap lingkungan sekitar seperti mudah marah dan tersinggung hingga perasaan gelisah dan putus asa yang dirasakan oleh responden. Perasaan tertekan yang disebabkan karena beban ekonomi akibat tingginya tanggungan biaya perawatan rumah sakit yang tidak sepenuhnya ditanggung oleh asuransi BPJS Kesehatan sedangkan para keluarga pasien tidak dapat bekerja dan beraktivias secara normal. Aktivitas keluarga pasien yang cenderung mononton yang dilakukan responden dalam jangka waktu yang lumayan panjang dan selama priode tertentu tidak banyak berinteraksi dengan orang lain selama menunggu dan mendampingi pasien di Ruang 
PICU juga menjadi salah satu penyebab kelelahan emosional yang dirasakan oleh responden.

Berdasarkan hasil wawancara kepada 12 orang responden, diketahui bahwa gejala kelelahan emsional yang dirasakan keluarga pasien ditampilkan dengan emosi yang sangat meluap-luap. Hal ini terlihat ketika peneliti berusaha menanyakan tentang kondisi pasien. Emosi ini merupakan luapan perasaan sedih yang mendalam dan gelisah yang dirasakan keluarga pasien selama keluarga pasien mendampingi dan menunggu pasien di Ruang PICU. Peneliti juga menanyakan keluarga pasien sebagai orangtua atau saudara dari pasien, diketahui bahwa keluarga pasien yang mana sebagian besar adalah orangtua pasien merasakan sedih dan stres yang cukup mendalam selama mendampingi anaknya melakukan proses perawatan. Kondisi pasien kritis pada ruang PICU menghadapkan keluarga pasien kepada perasaan stres, cemas, khawatir dan sedih yang terus menerus dan menghadapkan pasien dalam keadaan yang tertekan dan kelelahan secara emosional.

\section{b. Dimensi Kelelahan Fisik}

Berdasarkan penelitian yang telah dilakukan, dimensi kelalahan fisik responden berada pada kategori tinggi. Responden mengalami kesulitan bangun pagi dan tidur di malam hari, penurunan nafsu makan, mudahya responden terkena penyakit flu, sakit kepala atau migrain serta saki pada bagian leher, bahu serta punggung. Terjadinya perubahan pola tidur dan pola makan dan waktu istirahat. Responden terlihat kurang memperhatikan kondisi kesehatan dirinya sendiri dan hanya berfokus kepada kondisi kesehatan pasien.

Kurangnya fasilitas rumah sakit bagi keluarga pasien selama menunggu dan mendampingi keluarganya yang sedang menjalani proses perawatan intensif juga menjadi salah satu penyebab terjadinya kelelahan secara fisik yang dirasakan oleh responden. Berdasarkan hasil wawancara juga ditemukan informasi bahwa keluarga pasien merasakan ketidaknyamanan saat beristirahat karena tidak adanya tempat private yang tertutup untuk keluarga pasien beristirahat terutama pada malam hari. Keluarga pasien tidur dan beristirahat di lantai koridor rumah sakit dan akibatnya menjadi sering terserang penyakit terutama flu karena merasakan kedinginan terus menerus. Selain itu, fasilitas toilet umum yang kurang memadai juga menjadi masalah yang dialami keluarga pasien. sebanyak 12 responden yang diwawancarai oleh peneliti menyebutkan bahwa keluarga pasien merasakan kurang nyaman dengan toilet yang tersedia di rumah sakit. Keluarga pasien juga menyatakan bahwa sangat penting bagi mereka untuk dapat beribadah dengan tenang di ruang tunggu keluarga pasien, namun tidak adanya mushalla yang disediakan oleh pihak rumah sakit di area sekitar ruang pelayanan intensif, maka keluarga pasien harus berjalan keluar rumah sakit untuk shalat di masjid atau beribadah di lorong koridor rumah sakit. Halhal tersebut dianggap memperburuk keadaan dan kualitas istirahat dan kenyamanan fisik keluarga pasien dan berujung pada kelelahan fisik yang dirasakan oleh keluarga pasien.

\section{c. Dimensi Kelelahan Mental}

Berdasarkan penelitian yang telah dilakukan, diketahui bahwa kelelahan mental yang dialami oleh responden berada pada kategori sedang. Terjadinya kelelahan mental dalam tingkat sedang ini ditunjukkan melalui perasaan kurangnya kepedulian responden terhadap diri sendiri dan lingkungan sekitar serta orang lain, serta perasaan tidak kompeten, tidak berdaya dan gagal. Berdasarkan hasil 
jawaban kuesioner, salah satu gejala kelelahan mental yakni perasaan gagal, dalam penelitian ini diketahui responden mengalami kesulitan dalam menciptakan suasana yang santai dan rileks dengan pasien. Gejala kelelahan mental lainnya seperti perasaan tidak kompeten oleh responden ditampilkan dengan peran orangtua atau anggota keluarga terhadap pasien yang sedang sakit di Ruang PICU. Selain itu munculnya persepsi negatif terhadap orang lain disekitar responden serta persepsi negatif responden terhadap diri sendiri yang ditampikan dengan rasa merasa bersalah atas penyakit yang menimpa anak atau anggota keluarganya.

Ditinjau berdasarkan rekapitulasi hasil jawaban kuesioner, diketahui bahwa kelelahan mental responden berada dalam kategori sedang menuju kategori tinggi. Data ini diperkuat dengan hasil wawancara dan diketahui bahwa kondisi mental keluarga pasien tidak berada dalam kondisi stabil. Keluarga pasien terlihat selalu menangis dan gelisah ketika berbicara dengan peneliti. Sebagian keluarga pasien bahkan mengaku ingin menyerah dengan kondisi sakit yang diderita anaknya dan menerimanya sebagai takdir. Wawancara juga dilakukan peneliti dengan pihak pekerja medis di ruang PICU, menurut perawat yang bekerja di ruang PICU keluarga pasien sering mengalami pingsan dan serangan panik mendadak ketika kondisi anaknya berada dalam kondisi koma, banyak keluarga pasien yang tidak dapat mengontrol emosinya ketika pasien berada dalam kondisi kritis. Hal ini terjadi akibat kelelahan mental yang dirasakan keluarga pasien selama menunggu dan mendampingi pasien kritis dalam menjalani perawatan intensif di Ruang PICU.

\section{Analisis Masalah}

\section{a. Kelelahan Emosional yang Dirasakan Keluarga Pasien}

Pines dan Aronson (1998) menyatakan bahwa kelelahan emosional merupakan jantung atau faktor utama terjadinya kondisi burnout. Dimensi kelelahan emosional merupakan kelelahan yang berhubungan dengan perasaan pribadi seperti perasaan bosan, putus asa, mudah tersinggung, depresi, merasa tertekan, tidak berdaya, sedih yang mendalam, gelisah dan mudah marah. Dalam sindrom burnout, kelelahan emosional dapat ditunjukkan oleh perasaan tidak berdaya, tidak ada harapam, kekosongan, ketidakpuasan. George dan Jones (2014) dalam bukunya yang berjudul Burnout at Work mengatakan bahwa kelelahan emosional ditunjukkan oleh gejala-gejala seperti depresi dan tidak berdaya. Pines dan Aronson (1998) menyatakan bahwa ciri-ciri burnout pada kelelahan emosional adalah antara lain bosan, putus asa, mudah tersinggung, depresi, merasa tertekan, tidak berdaya, sedih yang mendalam, gelisah dan mudah marah.

Berdasarkan hasil penelitan, beberapa masalah yang ditemui pada keluarga pasien adalah rasa bosan yang disebabkan karena aktivitas responden yang menunggu pasien dan tidak melakukan aktivitas lainnya, lalu perasaan putus asa yang disebabkan karena kondisi kritis anak atau anggota keluarganya yang sedang menjalani perawatan intensif di Ruang PICU. Tekanan dari segi ekonomi juga menjadi salah satu permasalahan yang memicu terjadinya kelelahan responden pada dimensi emosional. Kelelahan emosional sangat dipengaruhi oleh rasa sedih yang mendalam. Sebagai keluarga pasien, terutama orangtua pasien yang mendampingi anaknya yang sedang kritis tentu akan merasakan emosi 
kesedihan yang mendalam bagi keluarga pasien. Selain itu, kecemasan yang dirasakan keluarga pasien yang disebabkan karena kondisi perkembangan kesehatan pasien. Emosi-emosi yang dirasakan keluarga pasien merupakan perasaan dan emosi yang telah lama dirasakan oleh keluarga pasien dan terjadi secara terus menerus dalam jangka waktu yang panjang, yakni selama pasien mengidap suatu penyakit serius dan selama pasien menjalani proses perawatan intensif.

\section{b. Kelelahan fisik yang Dirasakan Keluarga Pasien}

Pines dan Aronson (1998) menyatakan kelelahan fisik ditandai dengan ciri-ciri yakni kesulitan bangun pagi hari, sering terkena flu, perubahan kebiasaan makan, kesulitan tidur di malam hari, sakit kepala, tegang pada otot leher dan bahu, dan rasa sakit di punggung. George dan Jones (2014) mengatakan bahwa kelelahan fisik berkaitan dengan kekurangan energi fisik dan menunjukkan keluhan sakit fisik. Sekit secara fisik yang dirasakan individu dapat berupa sakit kepala, demam, sakit punggung, tegang pada otor leher dan bahu dan perubahanperubahan kondisi kesehatan fisik lainnya. Sedangkan individu yang mengalami penurunan energi fisik dicirikan dengan energi yang rendah seperti letih dan lemas. Pines dan Aronson (1998) juga menyatakan bahwa kelelahan fisik muncul sebagai hasil akhir dari kelelahan emosional.

Berdasarkan hasil penelitian, kelelahan fisik yang dialami keluarga pasien yang sedang menunggu dan mendampingi anak atau anggota keluarganya di Ruang PICU berada pada kategori tinggi. Kelelahan secara fisik, terutama sakit dan nyeri di bagian kepala dan punggung serta tegang pada otot leher dan bahu merupakan masalah yang terjadi akibat kurangnya fasilitas rumah sakit yang memadai bagi penunggu dan penjaga pasien, khususnya pasien kritis. Pasien kritis di ruang pelayanan intensif, salah satunya ruang PICU akan dirawat bersama-sama dengan beberapa pasien lainnya di dalam satu ruangan. Keluarga pasien yang bertugas untuk menjaga dan mendampingi pasien hanya difasiltasi satu ruang tunggu dan koridor luar ruangan steril untuk beristirahat.

Keluarga pasien yang mana dalam kondisi ini memiliki aktivitas yang cenderung monoton yakni hanya duduk mendampingi pasien, akan menyebabkan otot pinggang, leher dan bahu terasa sakit. Oleh karena itu diperlukannya istirahat yang cukup dan tempat berirtirahat yang nyaman agar memulihkan kembali otot-otot yang tegang. Akan tetapi, tidak tersedianya fasilitas rumah sakit mengharuskan keluarga pasien utnuk tidur diatas lantai koridor dengan bermodalkan alas tikar tipis untuk beristirahat. Kondisi tersebut juga berdampak pada kualitas istirahat atau tidur malam yang dirasakan keluarga pasien. Perubahan pola tidur akan menyebabkan perubahan pada kebiasaan makan dan akan berakibat pula pada kondisi daya imun tubuh. Berdasarkan hasil penelitian, diketahui bahwa sebagian besar responden merasakan kesusahan untuk bangun di pagi hari dan tidur di malam hari dan merasakan tidak memiliki nafsu makan serta merasa mudah sakit. Kondisi kelelahan fisik yang dirasakan oleh keluarga pasien sejalan dengan teori yang disampaikan oleh Pines dan Aronson (1998) bahwa rasa kelelahan yang berupa sakit fisik seperti sakit dan nyeri di bagian kepala, pinggang, bahu dan leher serta penurunan energi fisik yang disebabkan oleh perubahan pola makan dan pola tidur malam responden merupakan ciri-ciri dari kelelahan fisik. Kelelahan fisik yang dirasakan oleh responden 
tidak lepas dari kelelahan emosional dan tekanan psikologis yang dirasakan keluarga pasien.

\section{c. Kelelahan Mental yang Dirasakan Keluarga Pasien}

Pines dan Aronson (1998) menyatakan bahwa kelelahan mental merupakan rendahnya penghargaan diri dan depersonalisasi yang dicirikan dengan merasa kurang peduli dengan dirinya, merasa gagal, tidak berdaya dan tidak kompeten, kurang bersimpati pada orang lain, kecewa, menyalahkan diri sendiri, konsep diri yang rendah, sikap negatif terhadap orang lain serta tidak puas dengan jalan hidupnya sendiri.

Berdasarkan hasil penelitian, kelelahan mental pada keluarga pasien ditampilkan melalui perasaan kurangnya kepedulian responden terhadap diri sendiri dan lingkungan sekitar serta orang lain, serta perasaan tidak kompeten, tidak berdaya dan gagal yang ditunjukan oleh kesulitan responden untuk menciptakan suasana yang santai dan rileks dengan pasien, serta perasaan gagal, yakni terkait peran orangtua atau anggota keluarga terhadap pasien yang sedang sakit di Ruang PICU. Selain itu munculnya persepsi negatif terhadap orang lain disekitar responden serta persepsi negatif responden terhadap diri responden sendiri yang ditampilkan dengan rasa merasa bersalah atas penyakit yang menimpa anak atau anggota keluarganya dan tidak memiliki kepuasan terhadap jalan hidup yang ia miliki. Hal ini sejalan dengan teori Pines dan Aronson (1998) mengenai ciri-ciri kelelahan mental dalam dimensi burnout.

Kelelahan mental dirasakan sebagai wujud dari kelelahan emosional dan kelelahan fisik yang terus menerus terjadi. Freudenberger (1974) dalam Farber (1983) mengatakan bahwa kelelahan mental akan mengurangi efektivitas kemampuan individu dalam menjalani aktivitas sehari-hari. Kelelahan mental juga akan menjadi masalah yang serius jika berdampak pada gangguan mental. Oleh karena itu, perlunya keluarga memiliki coping strategy yang efektif untuk membantu mengatasi rasa stres yang dihadapi. Kelelahan mental yang dirasakan oleh keluarga pasien juga akan menjadi suatu masalah jika hal tersebut berujung pada ketidakberfungsian mental. Kesehatan mental keluarga pasien sebaiknya dipertimbangkan ke dalam prioritas pelayanan. Hal ini disebabkan karena kondisi kesehatan mental pasien juga dipengaruhi oleh kondisi mental orang terdekatnya yakni keluarga pasien itu sendiri, sehingga keluarga pasien diharapkan memiliki mental yang stabil dengan memiliki coping stress yang efektif dan mendapatkan dukungan mental dan emosional. Dukungan mental sangat diperlukan baik bagi pasien kritis maupun bagi keluarga pasien kritis.

\section{Analisis Kebutuhan}

Berdasarkan penelitian yang telah dilakukan, diketahui bahwa adanya burnout yang dialami oleh keluarga pasien, secara keseluruhan berada pada kategori tinggi. Burnout keluarga pasien pada dimensi kelelahan emosional dan kelelahan fisik berada pada tingkat tinggi sedangkan kelelahan mental yang dirasakan pada keluarga pasien atau responden berada pada tingkat sedang. Dimensi-dimensi burnout sangat berkaitan erat satu sama lain, hal ini disebabkan karena dimensi kelelahan emosional, kelelahan fisik dan kelelahan mental merupakan bentuk dan wujud dari sebab dan akibat antara satu dimensi dengan dimensi yang lain. Oleh karena itu, kebutuhan keluarga pasien terkait burnout yang dialami harus bersifat komprehensif. 
Merujuk pada jurnal penelitian Atika dan Halimuddin (2018) mengatakan bahwa kebutuhan keluarga pasien kritis yakni meliputi kebutuhan informasi, kebutuhan dukungan mental, kebutuhan rasa nyaman, kebutuhan berada dekat dengan pasien dan kebutuhan jaminan pelayanan. berdasarkan hasil analisis penelitian, adapun yang menjadi kebutuhan keluarga pasien dalam hal ini adalah kebutuhan dukungan mental, kebutuhan rasa nyaman dan kebutuhan informasi.

\section{Analisis Sistem Sumber a. Sistem Sumber Informal}

Sistem sumber infornal atau alamiah meliputi dukungan emosional, kasih sayang, nasehat, informasi yang dibutuhkan, bantuan berupa materi seperti uang serta pelayananpelayanan bersifat keluarga, kerabat dan lingkyngan tetangga maupun orang-orang lain yang bersedia membantu. Sistem sumber informal yang dimiliki responden adalah anggota keluarga lainnya yang dapat memberikan dukungan emosional dan memberikan penguatan antara satu anggota keluarga dan anggota keluarga lainnya. Selain itu dukungan emosional juga dapat diperoleh responden melalui kerabat atau tetangga yang memberikan dukungan dan empati.

\section{b. Sistem Sumber Formal}

Sistem sumber formal adalah segala sesuatu yang berasal dari luar individu yang keanggotaannya di dalam suatu organisasi atau asosiasi formal dapat memberikan bantuan atau pelayanan secara langsung kepada anggotanya. Dalam hal ini keanggotaan pasien dan keluarga pasien dalam asuransi kesehatan baik itu asuransi kesehatan yang berasal dari pemerintah seperti BPJS Kesehatan ataupun asuransi kesehatan yang berasal dari perusahaan swasta. Keanggotaan pasien dan keluarga pasien dalam asuransi kesehatan ini dapat membantu keluarga pasien dalam memecahkan masalah terkait keuangan sehingga keluarga pasien tidak terlalu terbebani dengan biaya perawatan rumah sakit yang tinggi. Selain itu keanggotaan pasien dan keluarga pasien pada organisasi-organisasi sosial yang bergerak di bidang kesehatan, seperti organisasi peduli anak kanker dapat diakses oleh responden dalam memenuhi dukungan emosional dan mental serta dapat membantu responden dalam memecahkan masalahnya, khususnya yang berkaitan dengan informasi pengobatan, perawatan serta pendampingan pasien.

\section{c. Sistem Sumber Kemasyarakatan}

Sistem sumber kemasyarakatan merupakan sumber lembaga-lembaga pemerintah ataupun orang-orang yang dalam kehidupannya berkaitan dengan sistem sumber kemasyarakatan, badan-badan pemerintah dan pelayanan umum. Pekerja sosial yang bekerja di bawah Dinas Sosial dapat menjadi sistem sumber bagi penanganan burnout di Rumah Sakit. Selain pekerja sosial, pihak RSUD itu sendiri dan orang-orang yang bekerja didalamnya yang bertugas melayani pasien seperti dokter, perawat serta apoteker, khususnya yang berada di Ruang PICU RSUD ULIN Banjarmasin juga menjadi sistem sumber. Kelelahan emosional yang dirasakan oleh responden dapat berkurang jika banyak pihak yang dapat menolong dan membantu responden dalam memecahkan masalah yang sedang mereka hadapi.

\section{KESIMPULAN}

Secara keseluruhan, kondisi burnout yang dialami keluarga pasien berada dalam kategori tinggi. Burnout yang dialami oleh keluarga pasien merupakan rasa keletihan baik secara fisik, emosional dan mental sebagai 
bentuk manifestasi dari tekanan psikologis dan stres yang dirasakan oleh keluarga pasien. Tekanan psikologis yang dialami oleh keluarga pasien disebabkan oleh kekhawatiran, ketakutan, cemas, depresi, putus asa, kelelahan, dan perasaan bersalah hingga perasaan tidak berdaya atau tidak berguna. Selain faktor tekanan psikologis, burnout yang dialami oleh keluarga pasien juga disebabkan oleh perubahan kehidupan sehari-hari saat anggota keluarga, khususnya dalam hal ini adalah anaknya, sedang dirawat di ruang perawatan intensif. Keterbatasan keluarga dalam pemenuhan kebutuhan sehari-hari, seperti kebutuhan istirahat tidur, kebutuhan nutrisi, pekerjaan dan tugas-tugas keluarga lainnya dapat berpengaruh terhadap kesehatan fisik, emosional hingga mental dari keluarga. Burnout juga dipicu oleh perasaan bosan karena mengalami pola kegiatan yang itu itu saja dalam periode waktu yang lama. Tekanan lainnya yang mempengaruhi burnout pada keluarga pasien adalah tingginya biaya perawatan rumah sakit yang tidak sepenuhnya tercover oleh asuransi BPJS Kesehatan, sedangkan di sisi lain keluarga juga tetap harus mencukupi biaya hidup dirinya sendiri dan anggota keluarga lain yang berada di rumah. Biaya perawatan dan juga pengobatan pasien yang tinggi serta lamanya pasien dirawat di ruang intensif berpengaruh pada biaya kehidupan sehar-hari keluarga secara keseluruhan. Kompleksnya masalah yang terjadi di dalam keluarga mampu mengakibatkan permasalahan psikososial, baik pada anggota keluarga sebagai penunggu pasien di Ruang PICU, maupun pada sistem dan fungsi keluarga secara keseluruan. Oleh karena itu dibutuhkan stress coping strategy untuk menurunkan tingkat stres yang disebabkan oleh kelelahan dan tekanan psikologis yang dirasakan responden. Peneliti merancang program berjudul "Upaya Pengurangan Tingkat Kelelahan Emosional Keluarga Pasien Kritis Melalui Kelompok Bantu Diri (Self Help Group)" di RSUD ULIN Banjarmasin. Tujuan dari program ini adalah untuk mengurangi tingkat kelelahan emosional keluarga pasien dengan memfasilitasi para keluarga pasien untuk mengeluarkan emosiemosi yang dirasakan serta memberikan kesempatan bagi para keluarga pasien untuk saling memberikan dukungan emosional dengan memanfaatkan kekuatan "mutual group". Metode pekerjaan sosial dengan kelompok dengan tipe self help group diharapkan dapat efektif dalam memberikan terapi dan diskusi kelompok kepada keluargakeluarga pasien yang sedang mengalami tekanan psikologis. Diharapkan pula dengan adanya rancangan program ini, keluarga pasien juga dapat memperoleh informasi dan pengetahuan serta sarana dan prasarana terkait coping strategy untuk mengurangi rasa stres dan kondisi burnout yang sedang dirasakan sehingga dapat memenuhi kebutuhankebutuhan keluarga pasien kritis, khususnya dari segi kebutuhan dukungan mental dan emosional.

\section{DAFTAR PUSTAKA}

Farber, B.A. 1983. Stress and Burnout in the Human Service Professions. USA Pregamon Press Inc.

Fenti Hikmawati. 2019. Metodologi Penelitian. Depok. Raja Grafindo Persada

Friedman, M.M., Bowden \& Jones. 2003. Family Nursing: Research, Theory, and Practice (5 ${ }^{\text {th }}$ ed.). Connecticut. Appleton \& Lange.

George dan Jones. 2005. Understanding and Organizational Behavior $4^{\text {th }} \quad$ Edition. Pearson Prentice Hall. 
Pines, A. Aronson. E., \& Elliot. 1998. Career Burnout: Causes and Cures. Free Press: New York.

Leiter, Michael P, Arnold B Bakker, Christina Maslach. 2014. Burnout at Work: A psychological perspective. New York. Psychology Press,

Nadirawati. 2018. Asuhan Keperawatan Keluarga. Bandung. Refika Aditama.

Sugiyono. 2016. Metode Penelitian Kuantitatif, Kualitatif dan $R \& D$. Bandung: Afabeta

\section{Sumber Lain}

Atika dan Halimuddin. 2018. Kebutuhan Keluarga Pasien di Unit Perawatan Intensif. Vol III.

Potter, B.A. 2005. Symptoms of burnout. Diakses pada 16 Juli 2019, dari http://www.docpotter.com/

Sutjipto, 2001. Apakah anda mengalami burnout?, Diakses pada 18 Juli 2019 dari https//depdiknas.go.id

Verhaeghe ST, van Zuuren FJ, Defloor T, Duijnstee MS, Grypdonck MH. 2007. How does information influence hope in family members of traumatic coma patients in intensive care unit ?. Vol $16: 88-97$. Diakses pada 25 November 2020 dari https//sciencepublishinggroup.com

Zahara Farhan, Kusman Ibrahim, Aat Sriati. 2014. Predikator Stres Keluarga Akibat Anggota Keluarganya Dirawat di General Intensive Care Unit. Vol. 46 (3). 